\title{
Risk factors for mediastinitis after coronary artery bypass grafting surgery
}

\author{
Fatores de risco para mediastinite após cirurgia de revascularização miocárdica
}

Michel Pompeu Barros de Oliveira SÁ ${ }^{1}$, Evelyn Figueira SOARES ${ }^{2}$, Cecília Andrade SANTOS $^{2}$, Omar Jacobina FIGUEIREDO ${ }^{2}$, Renato Oliveira Albuquerque LIMA ${ }^{2}$, Rodrigo Renda ESCOBAR ${ }^{3}$, Fábio Gonçalves de RUEDA ${ }^{4}$, Ricardo de Carvalho LIMA ${ }^{5}$

RBCCV 44205-1242

\section{Resumo}

Objetivos: A mediastinite é uma complicação grave da esternotomia mediana, estando associada a significativa morbidade e mortalidade. $O$ objetivo deste estudo é identificar fatores de risco para mediastinite em pacientes submetidos à cirurgia de revascularização miocárdica (CRM), sem o uso bilateral da artéria torácica interna (ATI), na Divisão de Cirurgia Cardiovascular do Pronto Socorro Cardiológico de Pernambuco - PROCAPE.

Métodos: Estudo retrospectivo compreendendo $\mathbf{5 0 0}$ pacientes consecutivos operados entre maio de 2007 e abril de 2010. Avaliaram-se 10 variáveis pré-operatórias, sete variáveis intraoperatórias e sete variáveis pós-operatórias possivelmente implicadas no desenvolvimento de mediastinite. Aplicaram-se análises univariada e multivariada por regressão logística.
Resultados: A incidência de mediastinite foi de 5,6\% $(n=28)$, com taxa de letalidade de 32,1\% $(n=9)$. Na análise multivariada por regressão logística, cinco variáveis permaneceram como fatores de risco independentes: obesidade (OR 2,60; IC 95\% 1,1-6,68), diabetes (OR 2,71; IC 95\% 1,18-6,65), tabagismo (OR 2,10; IC 95\% 1,12-4,67), uso de ATI pediculada (OR 5,17; IC 95\% 1,45-18,42) e CRM com circulação extracorpórea (OR 2,26, IC 95\% 1,14-5,85).

Conclusões: Este estudo identificou os seguintes fatores de risco independentes para mediastinite após CRM: obesidade, diabetes, tabagismo, uso de ATI pediculada e CRM com circulação extracorpórea.

Descritores: Fatores de Risco. Mediastinite. Revascularização Miocárdica.
1. Master degree at Faculdade de Ciências Médicas da Universidade de Pernambuco - FCM/UPE; Former internee; Divisão de Cirurgia Cardiovascular do Pronto Socorro Cardiológico de Pernambuco PROCAPE.

2. FCM/UPE Medical Undergraduated Student at FCM/UPE.

3. Cardiovascular Surgeon at the Divisão de Cirurgia Cardiovascular PROCAPE.

4. Health Science Postgraduate Student at FCM/UPE; Cardiovascular Surgeon at the Unidade de Recuperação Cardiotorácica (URCT) of PROCAPE.

5. Doctorate Degree in Cardiovascular Surgery from the Federal University of São Paulo - UNIFESP; Head of the Divisão de Cirurgia Cardiovascular do PROCAPE; Full Professor of Cardiothoracic Surgery Discipline at FCM/UPE.
This study was carrioed ou at Division of Cardiovascular Surgery of Pronto Socorro Cardiológico de Pernambuco - PROCAPE. University of Pernambuco - UPE. Nucleus of Research and Postgraduation of School of Medical Sciences of UPE, Recife,PE, Brazil.

Correspondence address:

Michel Pompeu Barros de Oliveira Sá. Av. Eng. Domingos Ferreira, 4172/405. Boa Viagem - Recife,PE, Brasil. CEP: 51021-040.

E-mail: michel_pompeu@yahoo.com.br

Support: Coordenação de Aperfeiçoamento de Pessoal de Nível Superior - CAPES

Artigo recebido em 14 de outubro de 2010 Artigo aprovado em 3 de janeiro de 2011 


\begin{abstract}
Objectives: Mediastinitis is a serious complication of median sternotomy and is associated to significant morbidity and mortality. The aim of this study is to identify risk factors for mediastinitis in patients undergoing coronary artery bypass grafting (CABG), without the use of bilateral internal thoracic artery (ITA), at the Division of Cardiovascular Surgery of Pronto Socorro Cardiológico de Pernambuco - PROCAPE.

Methods: A retrospective study of 500 consecutive patients operated on between May 2007 and April 2010. Ten preoperative variables, seven intraoperative variables and seven postoperative variables possibly involved in the development of postoperative mediastinitis were evaluated. Univariate and multivariate logistic regression analyses were performed.
\end{abstract}

\section{INTRODUCTION}

Mediastinitis is a deep wound infection following median sternotomy, with clinical evidence and/or microbiological commitment of the retrosternal space, associated with sternal osteomyelitis with or without its instability. It is one of the most serious complications of the median sternotomy, and it is associated to significant morbidity and mortality [1]. It is also known as deep sternal wound infection [1].

This is an entity with a low incidence, occurring in only $1 \%$ to $3 \%$ of patients after cardiac surgery [2]. However, when it occurs, is associated with high mortality rates, reaching $35 \%$ [3].

It has been shown that coronary artery bypass grafting $(\mathrm{CABG})$ is associated with a higher risk of developing mediastinitis compared to other procedures in cardiovascular surgery (valve surgery, correction of congenital heart disease) [4].

In recent years, studies [5-7] have emphasized the use of bilateral internal thoracic artery (ITA or mammary) as the major cause of higher incidence of mediastinitis in coronary artery bypass grafts. However, Sá et al. [4] performed a study in the Division of Cardiovascular Surgery of Pronto Socorro Cardiológico de Pernambuco - PROCAPE, noting an interesting aspect in comparison to these studies: in almost no patient in this service was performed bilateral ITA, running mostly only unilateral ITA. Even so, CABG in the realm of this hospital was associated with increased risk of developing mediastinitis compared to other procedures.

Therefore, the aim of this study is to identify risk factors for mediastinitis in patients undergoing $C A B G$ without the use of bilateral ITA in our institution.

\section{METHODS}

\section{Source population}

After approval by the ethics committee, we reviewed the records of consecutive patients undergoing CABG at
Results: The incidence of mediastinitis was $5.6 \%(\mathrm{n}=28)$, with a lethality rate of $32.1 \%(n=9)$. In multivariate analysis using logistic regression, five variables remained as independent risk factors: obesity (OR $2.60,95 \%$ CI 1.11 to 6.68), diabetes (OR 2.71, 95\% CI 1.18 to 6.65), smoking (OR $2.10,95 \%$ CI 1.12 to 4.67 ), use of pedicled internal thoracic artery (OR 5.17, 95\% CI 1.45 to 18.42) and on-pump CABG (OR 2.26, $95 \%$ CI 1.14 to 5.85).

Conclusions: This study identified the following independent risk factors for mediastinitis after CABG: obesity, diabetes, smoking, use of pedicled ITA and on-pump CABG.

Descriptors: Risk Factors. Mediastinitis. Myocardial Revascularization.

our institution from May 2007 to April 2010. At first, we identified 542 patients eligible for the study. Eight were excluded because they used bilateral ITA and 34 excluded due to lack of information from medical records, leaving 500 patients for data analysis, which complied with the minimum sample size calculated for the type of study required. Data collection was performed by trained staff (four people), and they did not know the purpose of the study (blind data collection).

\section{Sample size}

The sample was calculated from the work of Paul et al. [8]. It was selected the variable "additional procedure to CABG", which in this study had a frequency of $2.47 \%$ of mediastinitis among those non-exposed to this factor, with an odd ratio (OR) of 3.71. Considering $\alpha$ error as $5 \%, \beta$ error of $20 \%$, and the study power as $80 \%$, we obtained a minimum sample of 498 individuals for a cohort study.

\section{Study design}

It was a retrospective cohort study.

The dependent variable was mediastinitis after the surgical procedure. This variable was categorized into yes or no. Mediastinitis were considered with those who met at least 1 of the criteria according to the Centers for Disease Control and Prevention (CDC) [9]:

1. Patient has organisms cultured from mediastinal tissue or fluid obtained during a surgical operation or needle aspiration;

2. Patient has evidence of mediastinitis seen during a surgical operation or histopathologic examination;

3. Patient has at least 1 of the following signs or symptoms with no other recognized cause: fever $\left(38^{\circ} \mathrm{C}\right)$, chest pain, or sternal instability and at least one of the following:

a. Purulent discharge from mediastinal area;

b. Organisms cultured from blood or discharge from mediastinal area;

c. Mediastinal widening on x-ray. 
Isolated superficial infections from a sternal wound with stable and/or sterile sternal dehiscence and/or no macroscopic evidence of deep infection (purulent drainage) were not considered as having mediastinitis.

The independent variables were divided into three categories:

1. Pre-operative factors

a. Age $>70$ years

b. Gender (male or female)

c. Obesity (body mass index $\geq 30 \mathrm{~kg} / \mathrm{m}^{2}, \mathrm{BMI}$ );

d. Hypertension (reported by a patient and/or use of anti-hypertensive medication);

e. Diabetes (reported by a patient and/or use of oral hypoglicemic medication and/or insulin);

f. Smoking (reported by a patient; active or inactive for less than 10 years);

g. Chronic obstructive pulmonary disease - COPD (dyspnea or chronic cough AND prolonged use of bronchodilators or corticosteroids AND/OR compatible radiological changes - hypertransparency by hyperinflation and/or rectification of ribs and/or rectification diaphragmatic);

h. Renal disease (creatinine $\geq 2.3 \mathrm{mg} / \mathrm{dL}$ or pre-operative dialysis);

i. Previous cardiac surgery;

j. Ejection fraction $<50 \%$;

2. Intra-operative factors

a. Emergency surgery (during acute myocardial infarction, ischemia not responding to therapy with intravenous nitrates, cardiogenic shock);

b. Concomitant cardiac surgery;

c. Use of ITA;

d. Harvesting technique for ITA (pedicled - direct dissection of surrounding margin of tissue around the ITA with electrocautery - or skeletonized - artery dissection with scissors and clipping intercostal branches with metal clips without involving any margins tissue margins around ITA)

e. Number of bypass;

f. Use of cardiopulmonary bypass - CPB (on-pump or off-pump);

g. Time of CPB > 100 minutes;

3. Postoperative factors

a. Low cardiac output (need for inotropic support with dopamine $4 \mu \mathrm{g} / \mathrm{kg} / \mathrm{min}$ at least for a minimum of 12 hours or intraaortic balloon);

b. Reoperation (new sternotomy for bleeding, tamponade, or other reasons during the intra-hospital period)

c. Respiratory complications (pulmonary infection, acute respiratory distress syndrome, atelectasis, need for intubation for more than 48 hours);

d. Renal complications (creatinine $\geq 2.3 \mathrm{mg} / \mathrm{dL}$ or postoperative dialysis);

e. Hyperglicemia (first blood glucose after closure of skin $>200 \mathrm{mg} / \mathrm{dL}$ )

f. Blood transfusion (blood transfusion in the postoperative period before diagnostic definition of mediastinitis);

g. Multiple transfusions (more than three units of any blood products in the postoperative period before diagnostic definition of mediastinitis);

h. Infection at another site;

We also assessed the following characteristics: length of stay in intensive care unit (days) and hospital stay (days), the etiological agents involved (through the culture of material collected from the surgical site during reoperation for resolution of the complication); outcome (survival or death).

\section{Details of surgical procedures}

All patients received prophylactic antibiotics. It is part of the institutional protocol use intravenous cefazolin as the follows: $2 \mathrm{~g}$ as the initial dose during anesthesia induction, $1 \mathrm{~g}$ during entering CPB, $1 \mathrm{~g}$ every 4 hours during surgery, $1 \mathrm{~g}$ every 8 hours for 24 to 48 -hours after surgery.

All patients used bone wax for hemostasis of the sternal marrow (it is part of the protocol of our institution its use in all patients undergoing median sternotomy).

Patients were selected for CPB (on-pump or off-pump) and type of ITA harvesting technique (pedicled or skeletonized) according to the preference of the attending surgeon.

All mediastinitis cases were treated with specific antibiotics for germs identified on culture and antibiograms associated with reoperation with mediastinal toilet (many times as necessary).

\section{Data analysis}

Data were stored in SPSS program (Statistical Package for Social Sciences) version 15, from which calculations were performed with statistical analysis, and interpretation. The data storage was carried out in double-entry to validate and carry out analysis of data consistency, in order to ensure minimal error in recording information in software.

Univariate analysis for categorical variables was performed with the chi-square test or Fisher's exact test as appropriate. For continuous variables we used t-Student test. Verification of the hypothesis of equality of variances was performed using the Levene $\mathrm{F}$ test. Potential risk factors with $P<0.05$ in the univariate analysis were included in multivariate analysis in ascending order, which was performed by backward logistic regression. $P$ values $<0.05$ were considered statistically significant.

\section{RESULTS}

\section{Incidence}

Study population had a mean age of 62.14 years $( \pm 9.92)$ and $59.0 \%(n=295)$ were male and $41.0 \%(n=205)$ were 
female. It was found an incidence of $5.6 \%(n=28)$ of cases of mediastinitis. The time between the date of surgery and symptom onset ranged from 5 to 35 days with a mean of 13.57 days $( \pm 7.17)$.

\section{Univariate analysis}

Variables that were associated with increased risk of mediastinitis with $P<0.05$ were obesity, diabetes, smoking, preoperative renal disease, COPD, ejection fraction $<50 \%$, use of pedicled ITA, on-pump CABG, additional procedure to $\mathrm{CABG}$, renal complications, respiratory complications, infection at another site, re-operation and multiple transfusions. Data from the univariate analysis were shown in tables 1, 2 and 3 show.

Table 1. Incidence of mediastinitis according to preoperative variables (univariate analysis).

\begin{tabular}{|c|c|c|c|c|c|c|}
\hline \multirow{2}{*}{ Variable } & \multicolumn{2}{|c|}{ Mediastinitis } & \multicolumn{2}{|c|}{ TOTAL } & \multirow[t]{2}{*}{$P$ value } & \multirow[t]{2}{*}{ OR $(95 \% \quad$ CI) } \\
\hline & $\mathrm{N}$ & $\%$ & $\mathrm{~N}$ & $\%$ & & \\
\hline \multicolumn{7}{|c|}{ Age $>70$} \\
\hline Yes & 7 & 5.6 & 125 & 25.0 & $1.000^{(1)}$ & $1.00(0.41-2.41)$ \\
\hline No & 21 & 5.6 & 375 & 75.0 & & 1.00 \\
\hline \multicolumn{7}{|l|}{ Gender } \\
\hline Male & 19 & 6.4 & 295 & 59.0 & $0.237^{(1)}$ & $1.50(0.66-3.38)$ \\
\hline Female & 9 & 4.4 & 205 & 41.0 & & 1.00 \\
\hline \multicolumn{7}{|l|}{ Obesity } \\
\hline Yes & 9 & 12.2 & 74 & 14.8 & $0.014^{*(2)}$ & $2.97(1.29-6.84)$ \\
\hline No & 19 & 4.5 & 426 & 85.2 & & 1.00 \\
\hline \multicolumn{7}{|c|}{ Hipertensyon } \\
\hline Yes & 25 & 5.6 & 447 & 89.4 & $1.000^{(2)}$ & 1.00 \\
\hline No & 3 & 5.7 & 53 & 10.6 & & $1.01(0.30-3.48)$ \\
\hline \multicolumn{7}{|l|}{ Diabetes } \\
\hline Yes & 18 & 9.3 & 194 & 38.8 & $0.004 *(1)$ & $3.03(1.37-6.71)$ \\
\hline No & 10 & 3.3 & 306 & 61.2 & & 1.00 \\
\hline \multicolumn{7}{|l|}{ Smoke } \\
\hline Yes & 17 & 8.9 & 190 & 38.0 & $0.011 *(1)$ & $2.67(1.22-5.83)$ \\
\hline No & 11 & 3.5 & 310 & 62.0 & & 1.00 \\
\hline \multicolumn{7}{|c|}{ Renal disease } \\
\hline Yes & 6 & 14.0 & 43 & 8.6 & $0.025^{*(2)}$ & $3.21(1.22-8.40)$ \\
\hline No & 22 & 4,8 & 457 & 91,4 & & 1.00 \\
\hline \multicolumn{7}{|l|}{ COPD } \\
\hline Yes & 10 & 21.3 & 47 & 9.4 & $<0.001 *(2)$ & $6.42(2.76-14.96)$ \\
\hline No & 18 & 4.0 & 453 & 90.6 & & 1.00 \\
\hline \multicolumn{7}{|c|}{ Previous cardiac surgery } \\
\hline Yes & 5 & 9.6 & 52 & 10.4 & $0.196^{(1)}$ & $1.97(0.71-5.41)$ \\
\hline No & 23 & 5.1 & 448 & 89.6 & & 1.00 \\
\hline \multicolumn{7}{|c|}{$\mathrm{EF}<50 \%$} \\
\hline Yes & 12 & 9.2 & 130 & 26.0 & $0.036^{*(1)}$ & $2.25(1.03-4.89)$ \\
\hline No & 16 & 4.3 & 370 & 74.0 & & 1.00 \\
\hline
\end{tabular}

COPD: chronic obstructive pulmonary disease; $E F$ : ejection fractions.

*: Significant difference at $5.0 \%$

(1) Chi-square test

(2) Fisher's exact test 
Table 2. Incidence of mediastinitis according to intraoperative variables (univariate analysis)

\begin{tabular}{|c|c|c|c|c|c|c|}
\hline \multirow[t]{2}{*}{ Variable } & \multicolumn{2}{|c|}{ Mediastinitis } & \multicolumn{2}{|c|}{ TOTAL } & \multirow[t]{2}{*}{$P$ value } & \multirow[t]{2}{*}{ OR $(95 \% \quad$ CI $)$} \\
\hline & $\mathrm{N}$ & $\%$ & $\mathrm{~N}$ & $\%$ & & \\
\hline \multicolumn{7}{|l|}{ Number of bypass } \\
\hline 1 & 5 & 5.3 & 95 & 19.0 & \multirow{3}{*}{$0.648^{(1)}$} & $1.18(0.38-3.71)$ \\
\hline 2 & 15 & 6.6 & 227 & 45.4 & & $1.50(0.62-3.63)$ \\
\hline 3 or more & 8 & 4.5 & 178 & 35.6 & & 1.00 \\
\hline \multicolumn{7}{|l|}{ Use of ITA } \\
\hline No & 7 & 8.0 & 88 & 17.6 & \multirow[t]{2}{*}{$0.306^{(1)}$} & 1.00 \\
\hline Yes & 21 & 5.1 & 412 & 82.4 & & $0.62(0.24-1.67)$ \\
\hline Pedicled & 18 & 8.0 & 226 & 54.8 & \multirow[t]{2}{*}{$0.004 *(2)$} & $5.28(1.53-18.21)$ \\
\hline Skeletonized & 3 & 1.6 & 186 & 45.2 & & 1.00 \\
\hline \multicolumn{7}{|l|}{ Use of $\mathrm{CPB}$} \\
\hline Off-pump & 7 & 3.8 & 240 & 48.0 & \multirow[t]{2}{*}{$0.012 *(1)$} & 1.00 \\
\hline On-pump & 21 & 7.3 & 260 & 52.0 & & $2.92(1.15-7.72)$ \\
\hline$>100$ minutes & 12 & 11.2 & 107 & 41.2 & \multirow[t]{2}{*}{$0.124^{(1)}$} & $2.08(0.81-5.35)$ \\
\hline$\leq 100$ minutes & 9 & 5.9 & 153 & 58.8 & & 1.00 \\
\hline \multicolumn{7}{|c|}{ Additional procedure } \\
\hline Yes & 3 & 23.1 & 13 & 2.6 & \multirow[t]{2}{*}{$0.031^{*(1)}$} & $5.54(1.44-21.42)$ \\
\hline No & 25 & 5.1 & 487 & 97.4 & & 1.00 \\
\hline \multicolumn{7}{|l|}{ Emergency surgery } \\
\hline Yes & 1 & 12.5 & 8 & 1.6 & \multirow[t]{2}{*}{$0.371^{(2)}$} & $2.46(0.38-11.78)$ \\
\hline No & 27 & 5.5 & 492 & 98.4 & & 1.00 \\
\hline
\end{tabular}

ITA: internal thoracic artery ; CPB: cardiopulmonary bypass; *: Significant difference at $5.0 \%$; (1) Chi-square test; (2) Fisher's exact test

Table 3. Incidence of mediastinitis according to postoperative variables (univariate analysis)

\begin{tabular}{|c|c|c|c|c|c|c|}
\hline \multirow[t]{2}{*}{ Variable } & \multicolumn{2}{|c|}{ Mediastinitis } & \multicolumn{2}{|c|}{ TOTAL } & \multirow[t]{2}{*}{$P$ value } & \multirow[t]{2}{*}{ OR $(95 \%$ CI $)$} \\
\hline & $\mathrm{N}$ & $\%$ & $\mathrm{~N}$ & $\%$ & & \\
\hline \multicolumn{7}{|c|}{ Hyperglicemia } \\
\hline Yes & 10 & 4.6 & 217 & 43.4 & $0.398^{(1)}$ & $0.71(0.30-1.67)$ \\
\hline No & 18 & 6.8 & 283 & 56.6 & & 1.00 \\
\hline \multicolumn{7}{|c|}{ Low cardiac output } \\
\hline Yes & 6 & 7.5 & 80 & 16.0 & $0.426^{(2)}$ & $1.47(0.58-3.74)$ \\
\hline No & 22 & 5.2 & 420 & 84.0 & & 1.00 \\
\hline \multicolumn{7}{|c|}{ Renal complications } \\
\hline Yes & 9 & 24.3 & 37 & 7.4 & $<0.001 *(2)$ & $7.51(3.11-18.11)$ \\
\hline No & 19 & 4.1 & 463 & 92.6 & & 1.00 \\
\hline \multicolumn{7}{|c|}{ Respiratory complications } \\
\hline Yes & 10 & 16.9 & 59 & 11.8 & $0.001 *(2)$ & $4.80(2.10-10.97)$ \\
\hline No & 18 & 4.1 & 441 & 88.2 & & 1.00 \\
\hline \multicolumn{7}{|c|}{ Infection at another site } \\
\hline Yes & 16 & 35.6 & 45 & 9.0 & $<0.001 *(2)$ & $20.37(8.19-51.21)$ \\
\hline No & 12 & 2.6 & 455 & 91.0 & & 1.00 \\
\hline \multicolumn{7}{|c|}{ Re-operation } \\
\hline Yes & 18 & 64.3 & 28 & 5.6 & $<0.001 *(1)$ & $82.4(30.4-223.3)$ \\
\hline No & 10 & 2.1 & 472 & 94.4 & & 1.00 \\
\hline \multicolumn{7}{|c|}{ Blood transfusion } \\
\hline Yes & 21 & 7.2 & 293 & 58.6 & $0.070^{(1)}$ & $2.21(0.87-5.83)$ \\
\hline No & 7 & 3.4 & 207 & 41.4 & & 1.00 \\
\hline \multicolumn{7}{|c|}{ Multiple transfusion } \\
\hline Yes & 13 & 12,0 & 108 & 21.6 & $0.003 *(1)$ & $3.33(1.52-7.29)$ \\
\hline No & 15 & 3.8 & 392 & 78.4 & & 1.00 \\
\hline
\end{tabular}

ITA: internal thoracic artery ; CPB: cardiopulmonary bypass; *: Significant difference at $5.0 \%$; (1) Chi-square test; (2) Fisher's exact test 


\section{Multivariate analysis by logistic regression}

We identified the following independent risk factors for developing postoperative mediastinitis: obesity (OR 2.60, 95\% CI 1.11 to 6.68), diabetes (OR 2.71, 95\% CI 1.18 - 6.65), smoking (OR 2.10, 95\% CI 1.12 to 4.67), use of pedicled ITA (OR 5.17, 95\% CI 1.45 to 18.42) and on-pump CABG (OR $2.26,95 \%$ CI 1.14 to 5.85 ). Through specific tests, it was found that the model is well accepted $(P<0.001)$ and showed a degree of explanation of $94.4 \%$ (Table 4 ).

\section{Etiologic agents}

Of the etiologic agents isolated from the secretions of wounds obtained during reoperation for resolution of mediastinitis (Table 5), 46.4\% $(\mathrm{n}=13)$ had gram-positive cocci and the remaining gram-negative organisms or fungi. Negative culture was observed in $10.7 \%(\mathrm{n}=3)$ of the patients, probably due to early use of antibiotics.

Table 4. Multivariate analysis by logistic regression

\begin{tabular}{lcc}
\hline Variable & Adjusted OR (95\% CI) & $P$ Value \\
Obesity & $2.60(1.11-6.68)$ & $0.047^{*}$ \\
Diabetes & $2.60(1.11-6.68)$ & $0.047^{*}$ \\
Smoke & $2.10(1.12-4.67)$ & $0.007^{*}$ \\
Pedicled ITA** & $5.17(1.45-18.42)$ & $0.011^{*}$ \\
On-pump CABG*** & $2.26(1.14-5.85)$ & $0.044^{*}$ \\
\hline
\end{tabular}

*: Significant difference at 5.0\%; Constant $P<0.001$

**: Compared to Skeletonized ITA

***: Compared to Off-pump CABG

ITA: internal thoracic artery; CABG: coronary artery bypass graft.

Table 5. Analysis of etiologic agents in cases of mediastinitis in the postoperative period by the culture of exudates

\begin{tabular}{lcc}
\hline Isolated agents & $\mathrm{N}$ & $\%$ \\
\hline Staphylococcus aureus & 10 & 35.7 \\
Acinetobacter spp & 5 & 17.8 \\
Klebsiella pneumoniae & 4 & 14.3 \\
Staphylococcus epidermidis & 3 & 10.7 \\
Enterobacter spp & 3 & 10.7 \\
Pseudomonas aeruginosa & 2 & 7.1 \\
Fungi & 1 & 3.6 \\
Negative culture & 3 & 10.7 \\
\hline
\end{tabular}

\section{Evolution and outcome}

Patients who developed mediastinitis stayed more days in the intensive care unit $(17.79 \pm 16.63$ days versus $5.29 \pm$ 5.90 days; $P<0.001)$ and longer hospital stay $(50.21 \pm 30.46$ versus $31.84 \pm 20.64 ; P<0,001)$ compared with those who did not develop mediastinitis.

Nine $(32.1 \%)$ cases resulted in death.

\section{DISCUSSION}

In our study, the incidence of mediastinitis was $5.6 \%$ $(n=28)$, above the rates reported in other studies, ranging from $0.2 \%$ to $5.0 \%$ [10-12]. However, we should note two points. We are looking at a risk group for postoperative mediastinitis. A previous study at our institution [4] showed an incidence of $2.4 \%$ between 1038 cardiovascular surgeries (involving all types of surgeries - within the range defined in the literature) and $\mathrm{CABG}$ was associated with increased risk compared with other cardiac surgeries (95\% CI 3.44 to $8.30 ; P=0.0001$ ), justifying excess incidence in the present study.

Many factors have been associated with development of mediastinitis after cardiac surgery [13]. However, there is no consensus as to which factors are most important and how each is an independent predictor of risk for postoperative mediastinitis [13].

We observed obesity as an independent risk factor for postoperative mediastinitis. Milano et al. [14] discussed some factors that could explain why obesity is a risk factor. The dose of prophylactic antibiotics not corrected for body mass index of the patient, for example. They also suggest that skin preparation can be difficult and inappropriate because the deep folds of the skin and fatty tissue itself, which can act as a substrate for infection. Diez et al. [15] related the etiology of mediastinitis in obese patients with bradytrophic properties of adipose tissue that contribute to poor healing of wounds.

Diabetes is always a feared risk factor and viewed with caution by cardiovascular surgeons. As a consequence of its pathophysiology, microvascular changes and high levels of blood glucose may adversely affect the healing process $[16,17]$. In this study, diabetic patients were 2.7 times more likely (independent association) to develop mediastinitis compared with non-diabetics.

Another independent risk factor for mediastinitis in our study was smoking, being associated with 2.1 times more likely to present with mediastinitis compared with nonsmokers. Abboud et al. [18] also reported that smokers were 3.3 times more likely (independent association) had mediastinitis when compared with non-smokers in a case control study involving 117 patients (39 cases and 78 controls). 
We did not observe any differences in the incidence of mediastinitis among patients who used or not ITA. Since the study was retrospective, we could not identify the reasons why surgeons did not use ITA in certain cases. However, we found a higher incidence of mediastinitis in patients who used pedicled ITA compared with skeletonized ITA (statistically significant). In other words, the skeletonized ITA was a protective factor for postoperative mediastinitis, which was an independent association.

Several studies have shown favorable results to the use of skeletonized ITA [19-21]. Saso et al. [19] demonstrated that skeletonization of ITA in patients undergoing CABG was associated with a reduced incidence of deep sternal infection (OR $0.41,95 \%$ CI 0.26 to 0.64 ). This effect was even more evident when the specific analysis of diabetic patients (OR 0.19, 95\% CI from 0.1 to 0.34). Kai et al. [20] observed that incidence of deep sternal infection was significantly lower in the group that underwent $\mathrm{CABG}$ with the use of skeletonized ITA compared to the group using pedicled ITA (0.6\% versus $13.0 \% P=0.01)$.

These results were found, probably as a result of better sternal perfusion after ITA skeletonization compared to the pedicled ITA [22-28]. Boodhwani et al. [26] conducted a study with 48 patients, in which each individual was submitted to CABG using bilateral ITA, and all ITAs were dissected skeletonized in the left side and pedicled in the right side. Afterwards, patients were evaluated for sternal perfusion through scintigraphy (radio nuclear image). The authors found that sternal perfusion was increased in the skeletonized side compared with pedicle side (increase of $17.6 \%, P=0.03$ ). Kamiya et al. [27] showed that the oxygen saturation and blood flow in the microcirculation of the sternum tissue were better when using the skeletonized ITA compared to pedicled.

Our study found that on-pump CABG was an independent risk factor for developing postoperative mediastinitis. Bottio et al. [29] in a prospective study with 324 patients who underwent CABG, of whom 216 underwent on-pump CABG and 108 underwent off-pump, observed there was a lower incidence of sternal dehiscence with mediastinitis in the off-pump group, although this difference was not statistically significant. Mack et al. [30] observed a lower incidence of wound infection in patients undergoing off-pump compared to on-pump. Sabik et al. [31] in the Cleveland Clinic study involving 812 patients undergoing CABG (half on-pump and half off-pump) have identified a higher incidence of wound infection in the onpump group (2.0\% versus $0.2 \%, P=0.04)$. Reston et al. [32] in a meta-analysis of 53 studies involving a total of 46621 patients, found a lower incidence of wound complications, including superficial and deep infection in patients undergoing off-pump compared with on-pump CABG. The cardiopulmonary bypass time is a variable related to the duration of surgical procedure, and it was demonstrated as a possible risk predictor in some studies [33]. Although recognized in the literature as a possible risk factor, we observed no significant association between a prolonged cardiopulmonary bypass time and higher incidence of mediastinitis.

Our study showed that patients who developed mediastinitis stayed more time in the intensive care unit and had a higher length of hospital stay (statistically significant) compared with those who did not develop mediastinitis, which reflects the high morbidity and high costs involved with this complication. The lethality rate found $(32.1 \%)$ was similar to that observed in other studies $[18,34]$.

Other risk factors may be involved, but they are difficult to be measured. This are as follows: the aspect of the bone, which can sometimes show signs of osteoporosis, ischemia, the surgeon's ability, failure to follow the antisepsis procedures, errors in the sternotomy and in the sternum rewiring, as well as the excessive use of an electric scalpel. They are all factors not very often mentioned, but they can be important factors in the pathophysiology of mediastinitis [18].

The factor of greatest significance to the success of mediastinitis treatment is the early diagnosis and therapeutics. Predicting the infectious event after surgery to establish an early and adequate therapy interferes decisively to infection control and decrease of death cases caused by mediastinitis. In this scenario, predictive scores based on recognized risk factors are very useful. Recently, Magedanz et al. [35] developed a score for use in daily practice to calculate the risk of mediastinitis after CABG. The score includes variables collected routinely and easy to use, and has been already tested at other institutions [36].

We suggest that obese patients, diabetics and smokers should be considered for strategies to minimize the risk of infection, including, perhaps, weight loss before surgery, better control of blood glucose levels and reduction or abstinence from smoking. In fact, in patients who do not undergo bilateral ITA, the problem seems to be unrelated to use or not use unilateral ITA, but related to how ITA is harvested. Mainly, patients under an increased risk profile (obese, diabetics, smokers), should perhaps be considered for use of skeletonized internal thoracic artery and off-pump CABG, factors that are under partial dependency of surgeons.

\section{CONCLUSION}

This study identified the following independent risk factor for mediastinitis after $\mathrm{CABG}$ : obesity, diabetes, smoking, use of pedicled ITA and on-pump CABG. 


\section{REFERENCES}

1. Souza VC, Freire ANM, Tavares-Neto J. Mediastinitis following sternotomy for cardiac surgery: analysis of 10 years. Braz J Cardiovasc Surg. 2002;17(3):266-70.

2. Schimin LC, Batista RL, Mendonça FCC. Incidence of mediastinitis at the Hospital de Base do Distrito Federal in six years of study. Braz J Cardiovasc Surg. 2002;17(2):144-7.

3. Guaragna JC, Facchi LM, Baião CG, Cruz IBM, Bodanese LC, Albuquerque L, et al. Predictors of mediastinitis after cardiac surgery. Braz J Cardiovasc Surg. 2004;19(2):165-70.

4. Sá MPBO, Silva DO, Lima EN, Lima RC, Silva FP, Rueda FG, et al. Postoperative mediastinitis in cardiovascular surgery postoperation. Analysis of 1038 consecutive surgeries. Braz J Cardiovasc Surg. 2010;25(1):19-24.

5. Toumpoulis IK, Anagnostopoulos CE, Balaram S, Swistel DG, Ashton RC Jr, DeRose JJ Jr. Does bilateral internal thoracic artery grafting increase long-term survival of diabetic patients? Ann Thorac Surg. 2006;81(2):599-606.

6. Paulis R, Notaris S, Scaffa R, , Nardella S, Zeitani J, Del Giudice $\mathrm{C}$, et al. The effect of bilateral internal thoracic artery harvesting on superficial and deep sternal infections: the role of skeletonization. J Thorac Cardiovasc Surg. 2005;129(3):536-43.

7. Toumpoulis IK, Anagnostopoulos CE, Derose JJ Jr, Swistel DG. The impact of deep sternal wound infection on long-term survival after coronary artery bypass grafting. Chest. 2005;127(2):464-71.

8. Paul M, Raz A, Leibovici L, Madar H, Holinger R, Rubinovitch B. Sternal wound infection after coronary artery bypass graft surgery: validation of existing risk scores. J Thorac Cardiovasc Surg. 2007;133(2):397-403.

9. Horan TC, Andrus M, Dudeck MA. CDC/NHSN surveillance definition of health care: associated infection and criteria for specific types of infections in the acute care setting. Am J Infect Control. 2008;36(5):309-32.

10. El Oakley RM, Wright JE. Postoperative mediastinitis: classification and management. Ann Thorac Surg. 1996;61(3):1030-6.

11. Ståhle E, Tammelin A, Bergström R, Hambreus A, Nyström SO, Hansson HE. Sternal wound complications: incidence, microbiology and risk factors. Eur J Cardiothorac Surg. 1997;11(6):1146-53.

12. The Parisian Mediastinitis Study Group. Risk factors for deep sternal wound infection after sternotomy: a prospective, multicenter study. J Thorac Cardiovasc Surg. 1996;111(6):1200-7.
13. Friedman ND, Bull AL, Russo PL, Leder K, Reid C, Billah B, et al. An alternative scoring system to predict risk for surgical site infection complicating coronary artery bypass graft surgery. Infect Control Hosp Epidemiol. 2007;28(10):1162-8.

14. Milano CA, Kesler K, Archibald N, Sexton DJ, Jones RH. Mediastinitis after coronary artery bypass graft surgery. Risk factors and long-term survival. Circulation. 1995;92(8):2245-51.

15. Diez C, Koch D, Kuss O, Silber RE, Friedrich I, Boergermann J. Risk factors for mediastinitis after cardiac surgery: a retrospective analysis of 1700 patients. J Cardiothorac Surg. 2007;2:23.

16. Furnary AP, Zerr KJ, Grunkemeier GL, Starr A. Continuous intravenous insulin infusion reduces the incidence of deep sternal wound infection in diabetic patients after cardiac surgical procedures. Ann Thorac Surg. 1999;67(2):352-60.

17. Zerr KJ, Furnary AP, Grunkemeier GL, Bookin S, Kanhere V, Starr A. Glucose control lowers the risk of wound infection in diabetics after open heart operations. Ann Thorac Surg. 1997;63(2):356-61.

18. Abboud CS, Wey SB, Baltar VT. Risk factor for mediastinitis after cardiac surgery. Ann Thorac Surg. 2004;77(2):676-83.

19. Saso S, James D, Vecht JA, Kidher E, Kokotsakis J, Malinovski $\mathrm{V}$, et al. Effect of Skeletonization of the Internal Thoracic Artery for Coronary Revascularization on the Incidence of Sternal Wound Infection. Ann Thorac Surg. 2010;89(2):661-70.

20. Kai M, Hanyu M, Soga Y, Nomoto T, Nakano J, Matsuo T, et al. Off-pump coronary artery bypass grafting with skeletonized bilateral internal thoracic arteries in insulindependent diabetics. Ann Thorac Surg. 2007;84(1):32-7.

21. Milani R, Broffman PR, Guimarães M, , Barboza L, Tchaick RM, Meister Filho H, et al. Double skeletonized internal thoracic artery vs. double conventional internal thoracic artery in diabetic patients submitted to OPCAB. Rev Bras Cir Cardiovasc. 2008;23(3):351-7.

22. Menezes AM, Vasconcelos FP, Lima RC, Costa MG, Escobar MA. Technical aspects in skeletonization of the internal thoracic artery using an ultrasonic scalpel. Rev Bras Cir Cardiovasc. 2007;22(2):206-11.

23. Keeley SB. The skeletonized internal mammary artery. Ann Thorac Surg. 1987;44(3):324-5.

24. Higami T, Maruo A, Yamashita T, Shida T, Ogawa K. Histologic and physiologic evaluation of skeletonized internal thoracic artery harvesting with an ultrasonic scalpel. J Thorac Cardiovasc Surg. 2000;120(6):1142-7.

25. Lamm P, Juchem G, Weyrich P, Schütz A, Reichart B. The harmonic scalpel: optimizing the quality of mammary artery bypass grafts. Ann Thorac Surg. 2000; 69(6):1833-5. 
26. Boodhwani M, Lam BK, Nathan HJ, Mesana TG, Ruel M, Zeng W, et al. Skeletonized internal thoracic artery harvest reduces pain and dysesthesia and improves sternal perfusion after coronary artery bypass surgery: a randomized, doubleblind, within-patient comparison. Circulation. 2006;114(8);766-73.

27. Kamiya H, Akhyari P, Martens A, Karck M, Haverich A, Lichtenberg A. Sternal microcirculation after skeletonized versus pedicled harvesting of the internal thoracic artery: a randomized study. J Thorac Cardiovasc Surg. 2008;135(1):32-7.

28. Santos Filho EC, Moraes Neto FR, Silva RA, Moraes CR. Should the diabetics have the internal thoracic artery skeletonized? Assessment of sternal perfusion by scintillography. Rev Bras Cir Cardiovasc. 2009;24(2):157-64.

29. Bottio T, Rizzoli G, Caprili L, Nesseris G, Thiene G, Gerosa G. Full-sternotomy off-pump versus on-pump coronary artery bypass procedures: in-hospital outcomes and complications during one year in a single center. Tex Heart Inst J. 2003;30(4):261-7.

30. Mack MJ, Pfister A, Bachand D, Emery R, Magee MJ, Connolly $\mathrm{M}$, et al. Comparison of coronary bypass surgery with and without cardiopulmonary bypass in patients with multivessel disease. J Thorac Cardiovasc Surg. 2004;127(1):167-73.
31. Sabik JF, Blackstone EH, Lytle BW, Houghtaling PL, Gillinov AM, Cosgrove DM. Equivalent midterm outcomes after offpump and on-pump coronary surgery. $\mathrm{J}$ Thorac Cardiovasc Surg. 2004;127(1):142-8.

32. Reston JT, Tregear SJ, Turkelson CM. Meta-analysis of shortterm and mid-term outcomes following off-pump coronary artery bypass grafting. Ann Thorac Surg. 2003;76(5):1510-5.

33. Noyez L, van Druten JA, Mulder J, Schröen AM, Skotnicki SH, Brouwer RM. Sternal wound complications after primary isolated myocardial revascularization: the importance of post-operative variables. Eur J Cardiothorac Surg. 2001;19(4):471-6.

34. De Feo M, Renzulli A, Ismeno G, Gregorio R, Della Corte A, Utili R, et al. Variables predicting adverse outcome in patients with deep sternal wound infection. Ann Thorac Surg. 2001;71(1):324-31.

35. Magedanz EH, Bodanese LC, Guaragna JC, Albuquerque LC, Martins V, Minossi SD, et al. Risk score elaboration for mediastinitis after coronary artery bypass grafting. Rev Bras Cir Cardiovasc. 2010;25(2):154-9.

36. Sá MPBO, Figueira ES, Santos CA, Figueiredo OJ, Lima ROA, Rueda FG, et al.Validation of MagedanzSCORE as a predictor of mediastinitis after coronary artery bypass graft surgery. Rev Bras Cir Cardiovasc. 2011 (in press). 